\title{
The Implementation of Find Someone Who and Two Stay Two Stray Models to Improve Students' Self-Efficacy And Social Studies Learning Outcomes
}

\author{
Niki Kurnia ${ }^{1)}$, I Nyoman Sudana Degeng ${ }^{2)}$, Budi Eko Soetjipto ${ }^{3)}$ \\ ${ }^{1,2,3)}$ Basic Education Study Program, Graduate Program, Universitas Negeri Malang
}

\begin{abstract}
This research aims to knowing the improvement of students' self-efficacy and social studies learning outcomes result by implementing Find Someone Who and Two Stay Two Stray models. This research is a Classroom Action Research involving 24 students of the ninth grade of SMP Negeri 3 Sadaniang, Mempawah District, West Kalimantan Province. This study was conducted in two cycles. The data collection in this study was conducted by using observation, questionnaire, and interview. Technique of data analysis was done by using descriptive qualitative. The conclusion of this research is self-efficacy of the ninth grade students can be improved through the implementation of Find Someone Who and Two Stay Two Stray models. The recommendation that can be given is the teacher must design better and more various kind of lesson learning using Find Someone Who and Two Stay Two Stray models.
\end{abstract}

Keywords: Find Someone Who, Two Stay Two Stray, Self-Efficacy

\section{Introduction}

The teaching and learning process of Social Studies requires students to be creative and active in learning. Creativity and activity of students will be realized if students have good self-efficacy. Students' level of self-efficacy depends on the way teachers manage classroom learning process. The success of teachers in the management of the class depends on the methods and learning models used by teachers. Degeng (2013:39) described that the success of learning actually will be achieved through the efforts of teachers in carrying out learning activities. In this case the use of appropriate models and methods will certainly be able to improve students' self-efficacy so that the success of learning will be realized.

Degeng (2005: 156) mentioned that the learning outcome is a result of a variety of impacts that can serve as a reference indicator of the value on the use of a learning method under different conditions. Hamalik further (2014) revealed that learning outcome is a change in behaviour that occurs in humans, who previously do not know then they become know things and it can be assesed through three aspects namely cognitive, affective and psychomotor. Thus, it can be concluded that the learning outcomes are all forms of impact resulting from the application of a learning method. Based on the results of interviews with students in general they consider that the teaching and learning of social studies tends to be boring for most students because the materials taught are characterized by much memorization activities. If in the learning process teachers only use conventional methods and models such as lecturing then the learning activities that occur will tend to be passive characterized by students who just listen to the explanation given by teachers, and thus this kind of learning process will have an impact on low learning outcomes students have. Therefore, teachers are required to be more creative in using the model of learning so that it can generate motivation that can encourage higher students' self-efficacy. If students' self-efficacy is high then it will have an impact on better learning outcomes they have.

Based on the questionnaire distributed to students related to self-efficacy of the ninth grade students' in SMP Negeri 3 Sadaniang conducted in January 2017, it was found out that out of 24 students there were 7 students or $29.1 \%$ have very low category, of self-efficacy followed by 12 students or $50 \%$ with low category of self-efficacy, and 5 students or $20.9 \%$ with sufficient category. Meanwhile, the students' learning outcomes were found out to be low too. Of the 24 students, it was found that in the odd semester there were 19 students' have not completed the learning standard and 5 students have completed MCC (Minimal Completeness Criteria) of $\geq$ 75. From the results obtained from the pre study research it was clear that the problem arose was students' very low self-efficacy and learning outcomes. Thus, with regard to this, there should be some improvement done in learning so that students' self-efficacy and learning outcomes of social studies can increase.

There are several learning models that can have a positive impact on the improvement of self-efficacy and learning outcomes, two of which are Find Someone who and Two Stay Two Stray models of cooperative learning. These Models namely Find Someone Who and Two Stay Two Stray cooperative learning models were developed by Kagan in 2009. Find Someone Who model is a model to build a class building. According to Kagan (2009) this model works to develop, build class social skills, build knowledge and learning procedures. 
While Two Stray Two Stray model is one of the cooperative models which was also developed by Kagan. The Two Stay Two Stray model is a group learning system with the aim to make students work together be responsible, help each other solve problems, and encourage each other to get the learning betterment (Huda, 2013: 207).

The instructional syntax of Find Someone Who model according to Kagan (2009: 6.26) is as follows: (1) the students are mixed in the class, then they raise the hand until they find a partner who is not their group; (2) in pairs, partner A asks for questions on the worksheet, and partner B responds by answering the question. Furthermore, partner A records the answers given by partner B on the worksheet and gives appreciation to partner A; (3) partner B checks and evaluates the answers; (4) further questioning is done by partner B and partner A provides answers by doing the same activities as syntax 2 and 3; (5) then the couple shake hands and again raise his hand to find a new partner; (6) each student repeats steps 1 to 5 until the question on the worksheet is completed; (7) after the worksheet has finished the students sit back on the bench. And sitting students may be approached by other students who still want to find answers; (8) after returning to the group each student compares the answers they get, if there is a doubtful answer, they can raise their hand to ask another group again.

According to Huda (2013), the syntax of Two Stay Two Stray model can be seen from several stages as follows: (1) the teacher divides the students into several groups with each group consists of four students. The group formed is a heterogeneous group; (2) the teacher distributes sub-topics to each group to be discussed together with the members of each group; (3) students' work together in groups of four. It aims to provide opportunities for students to be actively involved in the thinking process; (4) after completing this step, two people from each group leave the group to visit another group; (5) two persons living in groups are assigned to share their work and information with guests from other groups; (6) guests excuse themselves and return to their own groups to report their findings from other groups; (7) groups match and discuss the results of their work; (8) each group presents their work.

Research by Nardi (2014) showed that the application of TSTS model and carousel feedback can improve self-efficacy and student's academic achievement in social studies learning. Research by Marlina, Soetjipto and Hadi (2016) found that the implementation of the rally coach model and Find Some One Who is believed to improve the learning outcomes of social studies subject. Furthermore, a research by Ismawati \&Hindarto (2011) also showed that the application of cooperative learning model with structural approach of TSTS model can improve physics learning outcomes of the tenth grade students' of SMA N 1 Boja. Then research by Effendi, Soetjipto \& Widiati (2016) showed that the application of TSTS and Carousel Feedback model collaboration can improve the motivation and learning result of social studies subject. Further research by Dewi, Soetjipto and Utaya (2016) showing the same result that the application of TSTS and Round Robin model can improve communication ability and learning result of social studies learning outcomes. Based on this background and previous research findings then this present research was conducted with the aim to find out the application of learning model of Find Someone Who and Two Stay Two Stray to improve students' self-efficacy and social studies learning outcomes.

\section{Method}

This study is classroom action research (CAR). The presence of researcher is as full participant who collaboratively work with classroom teacher in preparing lesson plans, instruments, and become model teachers. The location of this research was in SMP Negeri 3 Sadaniang having the address in Sekabuk Village, Sadaniang, Mempawah District, and West Kalimantan. The subjects in this study were students of class IX-A which amounted to 24 students, consisting of 12 male students and 12 female students.

Types of data collected were in the form of processes, events, numbers, and oral data. The data were collected by observation, questionnaire, and post test techniques at the end of the cycle. While the research procedure used two cycles; each cycle consists of four activities namely planning, action, observation, and evaluation and reflection. The criteria of mastery are determined as follows

Table 1. Criteria of Success per Cycle

\begin{tabular}{|c|c|c|c|}
\hline \multirow[t]{2}{*}{ No } & \multirow[t]{2}{*}{ Variable } & \multicolumn{2}{|l|}{ Criteria of success } \\
\hline & & Individual & classical \\
\hline 1 & Self-Efficacy & $\begin{array}{l}\text { Score } 34-45 \text { (high and very } \\
\text { high category) }\end{array}$ & $\begin{array}{l}85 \% \text { students get score of } \\
34-45 \text { (high and very high category) }\end{array}$ \\
\hline 2 & Learning outcome & $\mathrm{MCC} \geq 75$ & $85 \%$ students get $\mathrm{MCC} \geq 75$ \\
\hline
\end{tabular}

\section{Result}

The implementation of the Find Someone Who and Two Stay Two Stray models shows improvement. In cycle I the implementation of the find someone who model reached a percentage of $87.5 \%$ and increased into $95.31 \%$ in cycle II. While Two Stay Two Stray model in the first cycle reached a percentage of $71.67 \%$ and it 
increased into $95 \%$ in cycle II. Based on these data, both models are considered successful in this research. The increase can be seen in the figure below.

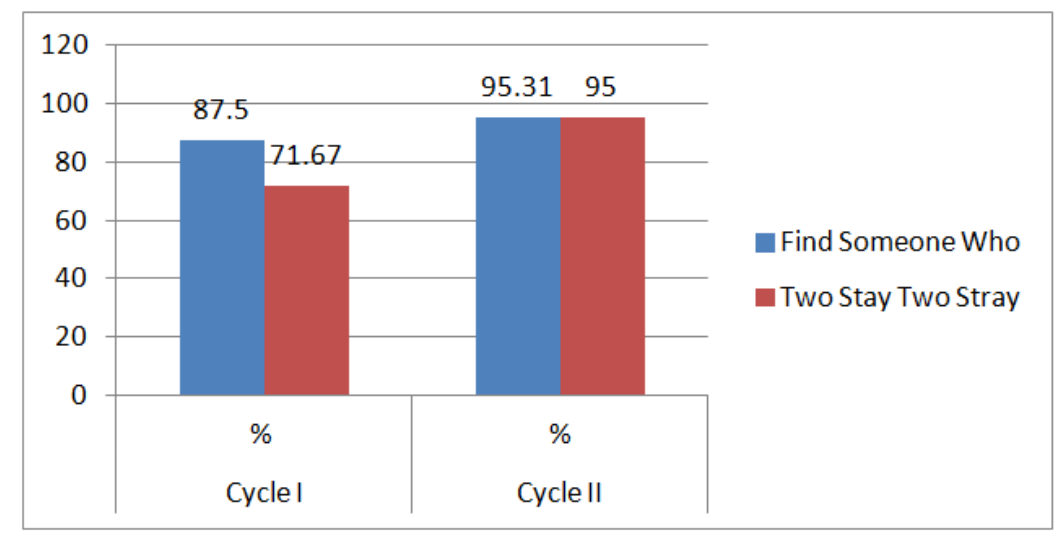

Figure 1. The percentage improvement on the model implementation

The average of self-efficacy score of students on pre-action was 23.5 and it increased into 29.8 in cycle I and 34.7 in cycle II. The increase can be seen in the following figure.

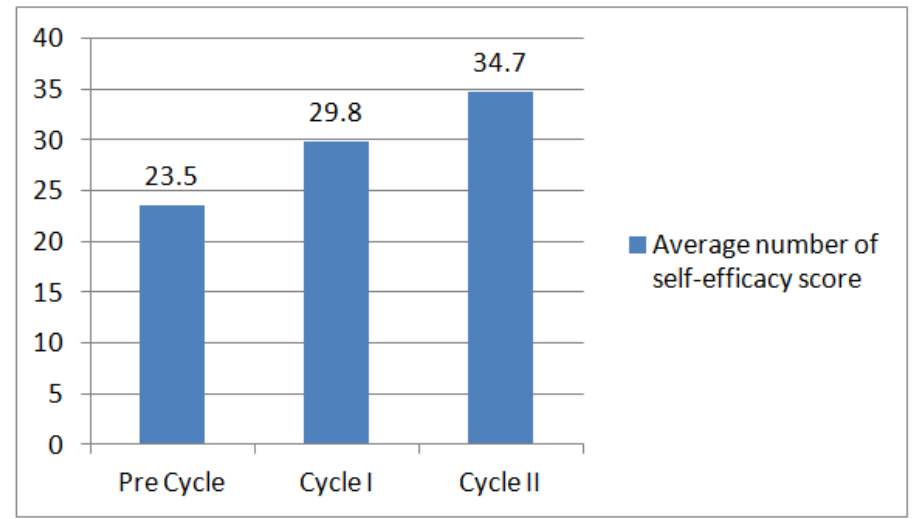

Figure 2 Comparison of mean self-efficacy score of students

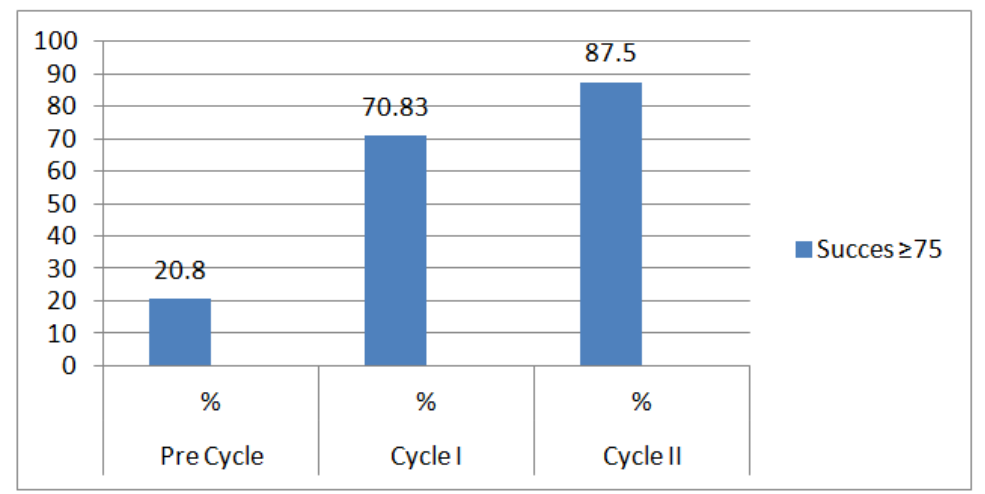

Figure 3 the percentage of comparison of learning outcomes

\section{Discussion}

Cooperative learning is learning in which students are divided into small groups with heterogeneous group members to work together and solve problems. Currently cooperative learning is very often used in learning because it is considered to be able to improve students' learning outcomes. Several previous studies have found that when students work together in groups the students will show good attitudes in achieving good goals and success (Deutsch, Thomas in Slavin, 2005:35).

From the results of observations made in learning, there are some advantages and disadvantages found in the model of Find Someone Who. The advantages are (1) making learning becomes more interesting, tedious and not boring; (2) motivating students to be more active; (3) enhancing students' cooperation in the classroom; 
(4) making students to be brave to express their opinions. While the disadvantages are (1) the class becomes noisy; (2) for novice teachers, it will be difficult for them to control the class; (3) group discussion is not maximal; (4) for underactive students, they may become less confident when answering questions in pairs.

Similar to Find Someone Who model, Two Stay Two Stray model also has advantages and disadvantages. In accordance to the opinion of Winataputra (2001) regarding the implementation of two stay two stray model, the advantages are (1) provide opportunities for students to be more creative in communicating with friends and groups of other groups; (2) provide chances for students to learn to be more actively motivated; (3) make students to be more courageous to express and convey their ideas or opinions; (4) increase student cohesiveness and confidence; (5) improve the efficacy and learning outcomes. While the shortcomings are (1) students who are not accustomed to learning groups feel alienated and difficult to cooperate so that they tend to be reluctant to learn in groups; (2) for teachers, this model implementation requires them to prepare a lot; (3) teachers tend to have difficulty in classroom management; (4) it takes a very long time.

Ormrod (2015: 20) says in general, self-efficacy is the judgment of a person about his or her own ability to perform certain behaviours or achieve certain goals. Self-efficacy first emerged in Bandura theory, the theory of social learning. One of the main concepts of social cognitive theory is self-efficacy. Bandura (in Schunk, 2012: 201) stated that self-efficacy is a person's belief about his or her ability to learn or perform actions at prescribed levels. Then if linked in the learning process of self-efficacy students are closely related to the success of students in learning.

Increased self-efficacy of students can be realized because the application of the model find someone who and two stay two stray proved to be able to improve students' creativity and confidence. In the model find someone who, students' self-confidence seeing from the instructional syntax can be seen when they began to ask questions and answer questions from their partners. The students' self-confidence grew because every student who answered the question must be able to answer the answer by correcting the answer. While on the two stay two stray stage model it seems that students' improvement in their self-efficacy occurs at the time of inter-visit activities between groups. Two people who are visited by representatives of other groups should answer confidently questions from the group of guests, and the two people who visit on their return to their respective groups should also be sure to present their findings from other groups. At the same time, students who present their results should be sure to answer or respond to questions from other groups.

The application of learning model find someone who and two stay two stray models give a positive impact in learning. From the initial meeting until the final meeting the students progressively showed a very rapid progress. Students who initially do not show participation in discussion and question and answer activities seem to show progress at the end of the cycle. Students become more confident in expressing their opinions; students also become brave to respond to questions from other groups. Students who were previously silent during discussion activities became more active and began to play an active role in discussion activities ranging from contributing answers, correcting group work to responding to other groups. In addition, in the process of question and answer session, students become more confident with the answers given to other pairs or groups. The atmosphere of learning in the classroom also becomes fun so students become more eager to learn social science subject. The implementation of these two models can also help students become more responsible, able to work together and can appreciate the opinions of others.

Self-efficacy data was obtained from a questionnaire filled by 24 students. The result is that there were $29.1 \%$ on the pre-action category with very low category, $50 \%$ with low category and $20.9 \%$ with sufficient category. In self-efficacy cycle I, it showed an increase to $4.2 \%$ with low category, $83.3 \%$ with sufficient category and $12.5 \%$ with high category. While in self-efficacy cycle II it showed increase to $12.5 \%$ with sufficient category and $79.17 \%$ with high category and $8.33 \%$ with very high category. Thus there is an increase from pre cycle to cycle II. This is in line with research conducted by Nurhaniyah (2015) which showed the results that the application of Find Someone Who and Flashcard Game model can improve students' motivation to learn. With a high motivation then it can be sure students' self-confidence will increase.

In this study the results show that student self-efficacy and learning outcome increased after the implementation of Find Someone Who and Two Stay Two Stray model. Using both models students become more active and more courageous and have confidence in answering questions. In addition these two models foster good communication among students so that they can share information that can train students to be more quickly understand the material. This will certainly give a good influence on improving student learning outcomes

In this study, the learning outcome measured is cognitively only. The analysis of student learning outcomes in the subjects of social studies shows that there are still many students who have not completed or have not met $\mathrm{KKM} \geq 75$. Of the 24 students in IX-A class there are 19 students or $79.2 \%$ who have not met the MMC and there are only 5 students or $20.8 \%$ are considered have completed the KKM. After the action on the first cycle, the learning results have increased from the post test result showing 7 students or $29.17 \%$ of have not 
completed the KKM and another 17 students or $70.83 \%$ of students have completed the KKM. While in the second cycle increased to 3 students or $12.5 \%$ unfinished and 21 students or $87.5 \%$ complete.

This research is in line with research by Mariyam (2012); Sulisworo (2014); Munandar (2015) who stated that the two stay two stray model is an excellent strategy to improve learning outcomes.

\section{Conclusion And Suggestion}

The application of the Find Someone Who and Two Stay Two Stray models can improve self-efficacy of the ninth grade students of class A of SMP Negeri 3 Sadaniang, West Kalimantan. This can be seen from the pre-action score which previously showed students' very low self-efficacy which was described as $20 \%$ students have sufficient category, $50 \%$ students with low category and $29.1 \%$ students with sufficient category. After the models were implemented, there was significant increase made. In the first cycle there were $12.5 \%$ students having high category, $83.3 \%$ with sufficient category and $4.2 \%$ with low category. While in cycle II there was an increase shown by 8.33 with very high category, $79.17 \%$ with high category and 12.5 with enough category. From very high and high category get percentage of $87.5 \%$. The results explain that the application of both models can help students to improve students' self-confidence and self-efficacy.

The application of the Find Someone Who and Two Stay Two Stray models can improve the learning outcomes of social studies subject of the ninth grade students of SMPN 3 Sadaniang West Kalimantan. The results showed that in the first cycle student learning outcomes achieve classical completeness of $70.83 \%$ and on the second cycle it reached $87.5 \%$.

Suggestions that can be given are social studies teachers should be more creative in using learning models that can stimulate students to be more motivated and confident in learning for example by using find someone who and two stay two stray model. In applying the model find someone who, there should be more teachers to control the class so that the atmosphere is not too crowded. In applying the two stay two stray model the teacher should go around in each group to observe and guide the students in the discussion. For future researchers, it is suggested to conduct research with a wider scope.

\section{References}

[1]. Degeng, I.N.S. 2005. Pendidikan FIP UM. Belajar dan Pembelajaran. Malang: Laboratorium Teknologi

[2]. Degeng, I.N.S. 2013. Ilmu Pembelajaran Klasifikasi Variabel untuk Pengembangan Teori dan Penelitian. Bandung: Aras Media.

[3]. Dewi, F.D.R., Soetjipto, B.E \& Utaya, S. 2016. The Implementation of TSTS and Round Robin Learning Models to Enhance Communication Skill and Social Studies learning Outcome For the Fourth Grade Students. Journal of Research \& Method in Education (IOSR-JRME), 6(3): 93-100.

[4]. Effendi, A., Soetjipto, B.E \& Widiati, U. 2016. The Implementation of Cooperative Learning Model TSTS and Carousel Feedback to Enhance Motivation and Learning Outcome for Social Studies. Journal of Research \& Method in Education (IOSR-JRME), 6(3) 131-136.

[5]. Hamalik, O.2014. Kurikulum Dan Pembelajaran. Jakarta : Bumi Aksara

[6]. Huda, M. 2013. Model-Model Pengajaran dan Pembelajaran (cetakan ke-2). Yogyakarta: Pustaka Pelajar.

[7]. Ismawati, N., Hindarto, N. 2011. Penerapan Model Pembelajaran Kooperatif dengan Pendekatan Struktural Two Stay Two Stray untuk Meningkatkan Hasil Belajar Siswa Kelas X SMA. Jurnal Pendidikan Fisika Indonesia, 7: 38-41.

[8]. Kagan, S \&Kagan, M. 2009. Kagan Cooperative Learning. San Clemente: Kagan Publishing.

[9]. Mariyam, S., Sumardi., Sukmanasa, E. 2012. Penerapan Model Pembelajaran Kooperati Two Stay Two Stray Untuk Meningkatkan Hasil Belajar Pada Mata Pelajaran Ilmu Pengetahuan Alam. Pendidikan Guru Sekolah Dasar, Fakultas Keguruan dan Ilmu Pendidikan, Universitas Pakuan. November ejournal.unpak.ac.id/download.php?file=mahasiswa\&id di akses tanggal 3 Agustus 2016.

[10]. Marlina, L., Soetjipto, B.E., Hadi, S. 2016. The Implementation of Rally Coach and Find Someone Who Model To Enhance Social Skills and Social Studies Learning Outcomes. Journal of Research \& Method in Education (IOSR-JRME), 6 (3): 86-92.

[11]. Munandar. 2015. The Effectiveness of Learning Two Stay Two Stray to Reduce Cognitive Load Accordance Student Learning Styles, Seminar Nasional XII Pendidikan Biologi. FKIP UNS 2015

[12]. Nardi, M. 2014. Penerapan Model TSTS dan Carousel Feedback Untuk Meningkatkan Efikasi Diri Dan Prestasi Akademik Siswa. Jurnal Pendidikan dan Kebudayaan Missio, 7(1): 11-19.

[13]. Nurhaniyah, B., Soetjipto, B.E \& Hanurawan, F. 2015. The Implementation of Collaborative Learning Model Find Someone who and Flash Card game to enhance Social Studies Learning Motivation for the Fifth Grade Students. Journal of Education and Practice, 6(17): 166-171.

[14]. Ormrod, J.E. 2015. Psikologi Pendidikan.Jakarta: Erlangga.

[15]. Schunk, D.H. 2012. Learning Theories: An Educational Perspectives, 6th, Boston: Pearson.

[16]. Slavin, R.E. 2005. Cooperative Learning Teori, Riset dan Praktik. Bandung: Nusa Media.

[17]. Sulisworo, D \& Suryani, F. 2014. The Effect of Cooperative Learning, Motivation and Information Technology Literacy to Achievement. International Journal of Learning \& Development, 4(2): 58-64. 